\title{
DNA-PCR and RT-PCR for the 18-kDa gene of Mycobacterium leprae to assess the efficacy of multi-drug therapy for leprosy
}

\author{
GUE-TAE CHAE, MIN-JOO KIM, TAE-JIN KANG, SEONG-BEOM LEE, HANG-KYE SHIN*, \\ JONG-PILL KIM*, YOUNG-HOON KO*, SUNG-HWA KIM† and NAN-HEE KIM* \\ Institute of Hansen's Disease, Department of Pathology, Catholic University of Korea, Seoul 137-701, \\ * Affiliated Hospital, Korean Leprosy Control Association, Euiwang City, Kyunggi-Do 437-823, †Catholic Skin \\ Clinic, Taegu City 702-200 and †Jesus Hospital, Leprosy Mission, Taegu City 704-080, Korea
}

\begin{abstract}
DNA-PCR and reverse transcription (RT)-PCR for the 18-kDa protein of Mycobacterium leprae were used to examine the efficacy of multi-drug therapy (MDT) in leprosy. MDT was administered for 0-24 months. Fourteen (63.6\%) of 22 patients showed positive PCR results after treatment for 12 months and the positive results decreased to $30 \%$ after 24 months of MDT. These results did not correlate with the bacterial index (BI) or the IgM antibody titre for the phenolic glycolipid (PGL)-1. One-dimensional densitometric analysis of agarose gels from PCR from the longitudinal study showed a gradual reduction of the 360-bp band after 12-24 months of MDT. RT-PCR for mRNA of the 18-kDa protein successfully tracked bacterial RNA changes in the biopsies and confirmed a decrease in the RNA of $M$. leprae in patients after MDT for 12 months. Thus, DNA- and RT-PCR for the 18-kDa protein of $M$. leprae are effective in assessing the efficacy of MDT for leprosy.
\end{abstract}

\section{Introduction}

Leprosy is a chronic infectious disease caused by Mycobacterium leprae. Although multi-drug therapy (MDT) has been very successful in reducing the prevalence of the disease, leprosy is still a major health problem globally. A sensitive and specific method for the detection of $M$. leprae would add an unbiased criterion to the available means of diagnosis and it might allow diagnosis of leprosy at a very early stage before the appearance of clinical signs. The lack of methods to identify $M$. leprae quickly and specifically has hampered research into the distribution and spread of the bacillus.

The assessment of chemotherapy efficacy in M. leprae infection is difficult, as the only reliable method for determining viability of the organism depends on its growth in mouse footpads. This technique is extremely expensive and time-consuming. It takes at least 10 months for organisms to grow and $>5$ years for lowgrade drug resistance to be proven.

Received 7 June 2001; revised version received 27 Oct.; accepted 5 Dec. 2001.

Corresponding author: Dr G.-T. Chae (e-mail guetae@cmc. cuk.ac.kr).
A widely used indirect measure of $M$. leprae viability is the morphological index (MI) [1]. Because M. leprae cannot be cultivated in vitro, the MI has become the standard laboratory assay for monitoring the short-term bactericidal activity of new anti-leprosy drugs. In this technique, the integrity of stained bacilli is judged microscopically and the proportion of morphologically intact bacilli is calculated. Although the idea of the technique is simple and it can be used in the field, in practice it requires skilled staff and precise staining conditions. Because of the lack of adequate standardisation and subjective interpretation, the MI is difficult to apply. Mycobacteria can be visualised by staining followed by microscopy, but this is not specific for $M$. leprae. As acid-fast staining requires at least $10^{4}$ organisms/g of tissue for reliable detection, sensitivity is low, particularly for patients in the tuberculoid leprosy spectrum when acid-fast bacilli (AFB) are rare or absent [2].

Current available serological tests show a relatively low sensitivity, which, in combination with the low prevalence of leprosy, limits their application to early case finding and detection of infection [3]. There are several reports on the measurement of phenolic glycolipid (PGL)-1 antigen titres in serum as a rapid marker for the efficacy of chemotherapy in patients 
with leprosy $[4,5]$, although the precise relationship of circulating antigen to bacterial viability is not clear.

Recently, several investigators have used the PCR to amplify various genomic sequences of $M$. leprae to improve detection when low numbers of bacteria are present [6-9]. DNA probes offer a route to the more sensitive detection and identification of bacterial DNA, e.g., M. leprae DNA in clinical samples, through the application of the PCR with $M$. leprae specific primers. PCR for identification of the DNA, which encodes $M$. leprae proteins of $65 \mathrm{kDa}$ [6], $36 \mathrm{kDa}$ [7] and $18 \mathrm{kDa}$ [8] and the repetitive sequences [9] of M. leprae, was introduced as a more sensitive and specific method than the empirical AFB examination.

In this study PCR was used as a measure of M. leprae viability on the premise that it detects nucleic acid, which must be present in the living organisms but which on cell death is more susceptible to degradation than other cell components. In this way, the efficacy of MDT was assessed in a longitudinal study.

An alternative detection method was also developed, which targets the abundant mRNA for the 18-kDa protein of $M$. leprae. Detection of RNA should give increased sensitivity over assays based on the detection of a single copy or even multiple copies of genomic sequences, as each cell contains $10^{3}-10^{4}$ copies of mRNA. An RNA-based detection method would be expected to better reflect the number of viable organisms because RNA is generally degraded within a few minutes of cell death. Thus, an RNA-based detection system might be useful for confirmation of the diagnosis in patients for whom a diagnosis is difficult to make, for assessing the efficacy of chemotherapy, in distinguishing relapse from late reaction in previously treated patients and for epidemiological studies.

To examine the efficacy of $18-\mathrm{kDa}$ PCR and RT-PCR for the assessment of MDT, this study compared the changes in the DNA of $M$. leprae with bacterial index (BI) and $\operatorname{IgM}$ antibody titre for phenolic glycolipid (PGL)-1 after MDT, determined the band thickness of PCR signals by the one-dimensional gel analysis method from representative biopsies for longitudinal study up to 12 and 24 months after MDT, and evaluated changes in the expression of mRNA for the $18-\mathrm{kDa}$ protein in M. leprae during MDT by RT-PCR.

\section{Materials and methods}

\section{Specimen collection and bacterial index (BI)}

Punch biopsies, slit smears and sera from the peripheral blood of 31 multi-bacillary case (MB) patients, with a positive BI of $>3$ at the time of diagnosis were collected from the Institute of Hansen's Disease in
Seoul, the Affiliated Hospital of the Korean Leprosy Control Association in Euiwang City, the Catholic Skin Clinic in Taegu City and the Jesus Clinic in Taegu City. Biopsies were performed on the most representative lesions with patient's consent at $0,6,9,12,18$ and 24 months during the course of MDT and stored in a cryovial. Biopsies for DNA-PCR were sent to the Institute of Hansen's Disease in ice, and specimens for RT-PCR were stored in liquid nitrogen and sent to the Institute of Hansen's Disease in a portable liquid nitrogen carrier.

The highest BI score in lesions was used to describe a patient's BI, because the average BI from lesions and routine sites not showing visible signs could reduce the $\mathrm{BI}$ more than warranted. BI scores were determined at the individual clinics. IgM antibody titre for PGL-1 was assessed at the Affiliated Hospital of the Korean Leprosy Control Association.

\section{Separation of $M$. leprae DNA from biopsies and infected footpads of nude mice}

After finely cutting half of the biopsy with no. 10 and 15 disposable scalpels in a Petri dish, $300 \mu \mathrm{l}$ of Dulbecco's phosphate-buffered saline (DPBS; pH 7.4) were added and the suspension was placed in a microcentrifuge tube. The suspension was homogenised by vortex mixing with three glass beads $(3 \mathrm{~mm}$ in diameter) for $3 \mathrm{~min}$. The supernate was recovered by centrifugation at $125 \mathrm{~g}$ for $10 \mathrm{~min}$ at $4^{\circ} \mathrm{C}$. A $50-\mu \mathrm{l}$ sample was subjected to freezing and thawing five times for $1 \mathrm{~min}$ each; $10 \mu \mathrm{l}$ were then used as a DNA template for $18-\mathrm{kDa}$ PCR. The rest of the DNA sample was stored at $-70^{\circ} \mathrm{C}$ until required.

Footpad granuloma from M. leprae-infected nude mice was dissected, soaked in iodine $1 \%$ solution and chopped finely with no. 10 and 15 disposable scalpels. The sample was then homogenised in $2 \mathrm{ml}$ of DPBS with 25-30 glass beads in a Mickle homogeniser (Mickle Laboratory Engineering, Surrey, UK). Ten $\mu 1$ of supernate were used as a DNA template and part of the supernate was stained with Ziehl-Neelsen's stain for acid-fast bacilli which were enumerated by the procedure of Shepard and McRae [10].

\section{8-kDa PCR}

A modification of a previously reported method [11] was used with the same primers used to amplify the DNA encoding the $18-\mathrm{kDa}$ protein and hot start PCR was accomplished. A reaction mixture of $10 \mu \mathrm{l}$ of template DNA and 100 pmole of primers was overlaid with mineral oil in a reaction tube, then denatured at $94^{\circ} \mathrm{C}$ for $5 \mathrm{~min}$ in a PCR 9600 heating cycler (Perkin Elmer, Branchburg, NJ, USA). A reaction mixture of $125 \mu \mathrm{M}$ dNTPs, Taq DNA polymerase (Boehringer Mannheim, Mannheim, Germany) $0.5 \mathrm{U}, 50 \mathrm{mM} \mathrm{KCl}$, $10 \mathrm{mM}$ Tris- $\mathrm{HCl}$ and $1.5 \mathrm{mM} \mathrm{MgCl}_{2}$ was added to make 
a total volume of $10 \mu \mathrm{l}$. The reaction consisted of 40 cycles of $30 \mathrm{~s}$ at $94^{\circ} \mathrm{C}, 30 \mathrm{~s}$ at $60^{\circ} \mathrm{C}, 1.5 \mathrm{~min}$ at $72^{\circ} \mathrm{C}$, followed by an extension at $72^{\circ} \mathrm{C}$ for $10 \mathrm{~min}$. Amplification product was confirmed as a 360 -bp band in agarose $2 \%$ gel electrophoresis at $80 \mathrm{~V}$. The DNA-PCR for the $18-\mathrm{kDa}$ protein was sensitive enough to detect as few as $10 \mathrm{M}$. leprae bacilli.

Longitudinal comparison of signals from DNAPCR for the 18-kDa protein by one dimensional densitometry

M. leprae DNA samples from serial biopsies stored after MDT for 0, 6, 12 and 24 months were used to prepare DNA for one-dimensional analysis of bands on agarose gel. Samples were centrifuged at $125 \mathrm{~g}$ at $4^{\circ} \mathrm{C}$ and the supernate was centrifuged at $15000 \mathrm{~g}$ for 20 min. The pellet was overlaid with $50 \mu \mathrm{l}$ of lysis buffer (proteinase $\mathrm{K} 10 \mu \mathrm{l}, 1 \mathrm{M}$ Tris- $\mathrm{HCl} 40 \mu \mathrm{l}, 50 \mu \mathrm{l}$ of Tween $800.5 \%$, DNAase- and RNAase-free water $400 \mu \mathrm{l})$ and incubated at $60^{\circ} \mathrm{C}$ for $2 \mathrm{~h}$, and then heat inactivated at $95^{\circ} \mathrm{C}$ for $10 \mathrm{~min}$. To purify the M. leprae DNA, an equal volume of phenol:chloroform:isoamyl alcohol (25:24:1) was added and agitated vigorously. After centrifuging at $15000 \mathrm{~g}$ for $10 \mathrm{~min}$, an equal volume of chloroform:isoamyl alcohol (24:1) was added to the supernate and the sample was recentrifuged. One-tenth of the volume of $5 \mathrm{M} \mathrm{NaCl}$ and three volumes of absolute ethanol were added to the supernate and the tubes were stored at $-70^{\circ} \mathrm{C}$ overnight. Sample were then centrifuged at $15000 \mathrm{~g}$ for $20 \mathrm{~min}$, the precipitate was dried and rehydrated with $20 \mu \mathrm{l}$ of distilled water and heated at $65^{\circ} \mathrm{C}$ for $5 \mathrm{~min}$. Ten $\mu \mathrm{l}$ of the precipitate were used as template DNA.

The thickness of bands on agarose gel electrophoresis was compared semi-quantitatively for samples obtained 0, 6, 12 and 24 months after MDT with Bio-1D V.96 software for Windows 95 (Vilber Lourmat, Marne La Vallee, France).

\section{RT-PCR for mRNA of the $18-k D a$ protein}

Total RNA of the M. leprae of infected nude mice and wedge or punch biopsy specimens were separated with Trizol (GibcoBRL Life Technologies, Grand Island, NY, USA) by the manufacturer's protocol. RNA contents were measured at $260 \mathrm{~nm}$ with a UV/VIS spectrophotometer 8450 A (Hewlett Packard, Palo Alto, CA, USA). To decontaminate genomic DNA, DNase I (Boehringer Mannheim, Mannheim, Germany) and RNase inhibitor (Promega, Madison, WI, USA) were added to $1 \mu \mathrm{g}$ of RNA and incubated at $37^{\circ} \mathrm{C}$ for $1 \mathrm{~h}$. The pure RNA fraction was extracted with phenol: chloroform:isoamyl alcohol and precipitated with ethanol.

The cDNA was synthesised from 1-5 $\mu \mathrm{g}$ of RNA with $250 \mathrm{ng}$ of random primer (Sigma) for $2 \mathrm{~min}$ and cooled rapidly in ice. The reaction mixture, with $0.5 \mathrm{~mm}$ dNTPs, 10 mM DTT, RNase inhibitor (Promega) 100 units and $\mathrm{H}$-superscript II reverse transcriptase (GibcoBRL) 200 units was added and held at $42^{\circ} \mathrm{C}$ for $1 \mathrm{~h}$ and then heated to $94^{\circ} \mathrm{C}$ for $5 \mathrm{~min}$. The $18-\mathrm{kDa}$ PCR confirmed that the cDNA came from the RNA of $M$. leprae. The single strand of the DNA was synthesised by the addition of $50 \mathrm{mM}$ Tris- $\mathrm{HCl}, 5 \mathrm{mM} \mathrm{MgCl}_{2}$, $10 \mathrm{mM}\left(\mathrm{NH}_{4}\right)_{2} \mathrm{SO}_{4}, 10 \mathrm{~mm}$ DTT, $1.5 \mathrm{mM}$ dNTPs, $7 \mathrm{U}$ of RNase $\mathrm{H}$ and $1 \mathrm{U}$ of DNA polymerase, and incubation at $16^{\circ} \mathrm{C}$ for $4 \mathrm{~h}$.

To validate the effectiveness of RT-PCR for $18-\mathrm{kDa}$ mRNA of $M$. leprae, it was compared with the results of RT-PCR for the 16S rRNA [12] with serial dilution of $M$. leprae from infected nude mice.

\section{IgM antibody titre for PGL-1}

IgM antibody titre for PGL-1 antigen was determined by the ELISA method described previously [4] with sera from patients on MDT. The absorbance was read at $492 \mathrm{~nm}$ with a Thermonax plate reader (Molecular Device, Sunnyvale, CA, USA). Values $>0.200$ were considered positive.

\section{Results}

A longitudinal study of the changes in $M$. leprae in biopsy specimens was conducted by DNA-PCR and RT-PCR for the $18-\mathrm{kDa}$ protein. The DNA-PCR had a detection limit of $10 \mathrm{M}$. leprae bacilli (Fig. 1). Twentytwo patients who had a positive BI of $>3$ at the start of MDT gave positive $18-\mathrm{kDa}$ PCR results. The PCR result remained positive at 0 month (22/22 patients), 6 months (21/22), 12 months (14/22) and 24 months (6/ 20) after MDT (Table 1). There were no positive PCR results in patients with a BI score of $\leqslant 1$ during treatment (Table 2). In the case that showed a negative PCR result but a BI of 4, the PGL-1 titre supported the high score (Table 2, patient no. 19). Thus, there was not a close correlation between IgM titre for PGL-1, BI and PCR positivity.

However, when one-dimensional densitometry of the bands from serial biopsies was performed, it demonstrated a clear and gradual decrease after MDT for 12 and 24 months (Table 2). When biopsy specimens with the highest BI from each patient were chosen for analysis, four of 11 patients had a highest BI of $\leqslant 2.0$ for the specimens. Of the specimens from the four patients, one was PCR positive and the others were PCR negative (Table 3 ). There is a slight correlation between BI and PCR results.

The RT-PCR method based on the 18-kDa mRNA showed successful RNA separation and synthesis of cDNA as confirmed by the amplification of the gene for the $18-\mathrm{kDa}$ protein. The results of the RT-PCR 


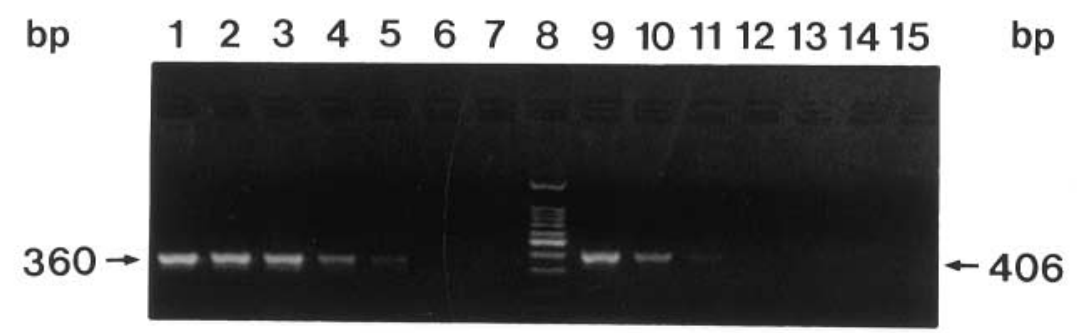

Fig. 1. RT-PCR for $18 \mathrm{kDa}$ mRNA detected up to $10^{2} M$. leprae (360-bp band), compared with RT-PCR for $16 \mathrm{~S}$ rRNA of $M$. leprae which detected from $10^{6}-10^{4} M$. leprae (406-bp band) in serial dilution of M. leprae from infected nude mice. Lanes 1-7, RT-PCR for 18-kDa mRNA with serial dilution of M. leprae: $1,10^{6}$ M. leprae; $2,10^{5}$ M. leprae; 3, $10^{4}$ M. leprae; 4, $10^{3}$ M. leprae; 5, $10^{2}$ M. leprae; 6, $10^{1}$ M. leprae, 7, $10^{0}$ M. leprae, 8, 100-bp marker. Lanes 9-15, RT-PCR for 16S rRNA: 9, $10^{6} M$. leprae; $\mathbf{1 0}, 10^{5}$ M. leprae; $\mathbf{1 1}, 10^{4}$ M. leprae; $\mathbf{1 2}, 10^{3}$ M. leprae; $\mathbf{1 3}, 10^{2}$ M. leprae; $\mathbf{1 5}, 10^{1}$ M. leprae.

showed a detection limit of $\geqslant 10^{2} M$. leprae bacilli, which was more effective than the results from RTPCR, that targets 16S rRNA with serial dilution of $M$. leprae (Fig. 1). RT-PCR for the $18-\mathrm{kDa}$ gene showed gradual reductions in band intensity during MDT over 0, 3, 6 and 12 months (Fig. 2). There were marked changes in band thickness in RT-PCR of patient nos. 16 and 18 , but no change in the intensity of bands was found in patient no. 31 after MDT for 0,3 and 12 months (Fig. 2).

\section{Discussion}

The present study shows that DNA-PCR for the $18-\mathrm{kDa}$ gene detected $M$. leprae DNA for up to 24 months qualitatively and serial decreases of band density from biopsies semi-quantitatively. The introduction of PCR improved the diagnosis and follow-up of MDT. PCR has an advantage over BI and IgM antibody titre for PGL-1 because it provides proof of the changes in the numbers and the viability of $M$. leprae in tissue after MDT. The results of DNA-PCR in the present study (Table 1) were different from the results of those of Jamil et al., who reported that c. $50 \%$ of patients showed a negative PCR after treatment for 1-6 months [13]. Others have reported a steep decrease in positive PCR results in 8 of 13 patients at 6 months and in 5 of 11 patients at 24 months [14]. Tissue fluid from a slit smear was often used as an alternative to skin biopsy, but the PCR results were observed to fall faster than when biopsy specimens were used $[15,16]$.

The differences noted above could depend on the

Table 1. Results of DNA-PCR for the 18-kDa gene after MDT for $0-24$ months

\begin{tabular}{lcc}
\hline $\begin{array}{l}\text { Length of } \\
\text { MDT (months) }\end{array}$ & $\begin{array}{c}\text { Number of } \\
\text { patients tested }\end{array}$ & $\begin{array}{c}\text { Number (\%) of } \\
\text { patients with } \\
\text { positive PCR result }\end{array}$ \\
\hline 0 & 22 & $22(100)$ \\
6 & 22 & $21(95.5)$ \\
12 & 22 & $14(63.6)$ \\
24 & 20 & $6(30)$ \\
\hline
\end{tabular}

method used to separate the DNA and the target DNA to be amplified. While other studies separated DNA from frozen sections, the present study used biopsy specimens; and with respect to the amplified gene, the gene for the $18-\mathrm{kDa}$ protein was targeted. However, others have used the pra gene for the $36-\mathrm{kDa}$ protein. Recently, Donoghue et al. reported that PCR based on the amplification of the gene for the $18-\mathrm{kDa}$ antigen rather than the $36-\mathrm{kDa}$ antigen has an advantage in terms of its lower detection limit for M. leprae [17]. For routine $18-\mathrm{kDa} \mathrm{PCR}$, the present study adopted physical methods (freezing-thawing) to extract the $M$. leprae DNA, but to compare the thickness of bands from serial biopsies a proteinase $\mathrm{K}$ and extraction methods were used, which gave more favourable results than the physical method.

DNA-PCR identified only the presence of $M$. leprae, but it did not determine the viability of the organisms. Recently, RT-PCR for 16S rRNA of M. leprae, which evaluates the viability of $M$. leprae in the lesion after MDT, was developed $[12,18]$. RT-PCR for mRNA of the $18-\mathrm{kDa}$ gene gave clearer band changes than 18$\mathrm{kDa}$ PCR during MDT. RT-PCR showed a gradual decrease in the intensity of PCR bands over $0,3,6$ and 12 months of MDT (Fig. 2). This means that $18-\mathrm{kDa}$ mRNA is one of the well-conserved RNAs like 16S rRNA. The results showed a step-wise reduction in the strength of bands after MDT for 1 year. The other method, NASBA, which targets 16S rRNA, resulted in a steep decrease in $5(19.2 \%)$ of 26 patients at 6 months and in $1(16.7 \%)$ of 6 patients $(16.7 \%)$ at 12 months [19]. The cause of differences in results seems to be associated with the frozen section specimen preparation used.

The MDT regimen used was based on rifampin, clofazimine and DDS (dapsone). However, rifampin, ofloxacin and minocyline (ROM) were prescribed for patients who refused to take clofazimine fearing skin discoloration.

No change in the intensity of bands was found in patient no. 31 after 0,3 and 12 months of MDT (Fig. 2). The patient was subjected to treatment with 
Table 2. Changes in one-dimensional densitometry of agarose gel electrophoresis of serial biopsies, highest score of BI and IgM antibody titre by ELISA for PGL-1 after MDT

\begin{tabular}{|c|c|c|c|c|c|}
\hline $\begin{array}{l}\text { Patient } \\
\text { no. }\end{array}$ & $\begin{array}{c}\text { MDT } \\
\text { length } \\
\text { (months) }\end{array}$ & $\begin{array}{l}\text { PCR result } \\
\text { after } \mathrm{MDT}\end{array}$ & $\begin{array}{l}\text { Width of band } \\
\text { from } \\
\text { serial biopsies }\end{array}$ & $\begin{array}{c}\text { High score of } \\
\text { BI }\end{array}$ & $\begin{array}{l}\text { IgM antibody } \\
\text { for PGL-1 } \\
\text { (ELISA unit) }\end{array}$ \\
\hline \multirow[t]{2}{*}{4} & 0 & + & 0.164 & 3 & 0.067 \\
\hline & 12 & - & 0.000 & 1 & 0.024 \\
\hline \multirow[t]{2}{*}{5} & 0 & + & 0.823 & 5 & 0.853 \\
\hline & 12 & + & 0.478 & 5 & 0.345 \\
\hline \multirow[t]{2}{*}{18} & 0 & + & 1.253 & 4 & 0.686 \\
\hline & 12 & + & 0.752 & 6 & 0.959 \\
\hline \multirow[t]{2}{*}{19} & 0 & + & ND & 5 & 1.472 \\
\hline & 24 & - & 0.000 & 4 & 1.522 \\
\hline \multirow[t]{2}{*}{22} & 0 & + & 0.970 & 6 & 1.452 \\
\hline & 33 & + & 0.219 & 5 & 1.268 \\
\hline \multirow[t]{2}{*}{24} & 0 & + & 0.304 & 3 & 0.021 \\
\hline & 24 & - & 0.000 & 0 & 0.005 \\
\hline \multirow[t]{2}{*}{25} & 0 & + & 0.890 & 4 & 0.265 \\
\hline & 24 & + & 0.130 & 2 & 0.054 \\
\hline \multirow[t]{2}{*}{28} & 0 & + & 1.854 & 5 & 1.109 \\
\hline & 24 & + & 0.874 & 5 & 0.649 \\
\hline \multirow[t]{2}{*}{29} & 0 & + & 1.061 & 3 & 0.963 \\
\hline & 24 & - & 0.000 & 1 & 0.120 \\
\hline
\end{tabular}

$\mathrm{ND}$, not done.

ofloxacin and was found to have a mutation in the gyrA of M.leprae in single-stranded conformational polymorphism analysis (data not shown). The gyrA gene is known as a target gene of the quinolones. Therefore, it is likely that the mutation in the gyrA induced the resistance to ofloxacin, one of the quinolones, and that no change was found in the intensity of bands.

It usually takes 6 or 12 months [16] for a patient to become PCR-negative after MDT and sometimes the patients show higher BI scores of up to 4-6 positive during the treatment periods, which represents a large discrepancy between the results of BI and PCR. PCR results seemed to be better correlated with the morphological index (MI) than the BI [13]. PCR titre with 36-kDa PCR which amplifies the DNA of the pra gene has demonstrated a rapid and steep decrease to

Table 3. Comparison of PCR amplification for the detection of $M$. leprae in biopsy specimens with bacteriological findings for biopsy and slit-skin smear specimens from leprosy patients after MDT for 12 or 24 months

\begin{tabular}{lccc}
\hline & & \multicolumn{2}{c}{$\begin{array}{c}\text { Number (\%) of PCR results that } \\
\text { were }\end{array}$} \\
\cline { 3 - 4 } $\mathrm{BI}^{*}$ & $\mathrm{n}$ & positive & negative \\
\hline 0 & 1 & $0(0)$ & $1(100)$ \\
$0.1-1.0$ & 2 & $0(0)$ & $2(100)$ \\
$1.1-2.0$ & 1 & $1(100)$ & $0(0)$ \\
$2.1-3.0$ & 0 & $0(0)$ & $0(0)$ \\
$3.1-4.0$ & 2 & $1(50)$ & $1(50)$ \\
$4.1-5.0$ & 4 & $4(100)$ & $0(0)$ \\
$5.1-6.0$ & 1 & $1(100)$ & $0(0)$ \\
Total & 11 & $\ldots$ & $\ldots$ \\
\hline
\end{tabular}

*Bacteriological findings based on microscopic examination of slitskin smears and biopsy specimens. Of the BI based on slit-skin smears and biopsy samples, only the higher BI was chosen for analysis. zero between 12 months and 24 months after the initiation of MDT [13, 15]. These results are not consistent with the fact that the BI usually decreases after MDT to a level of $\log _{10} 1.7-1.9$ in MB cases within 12-24 months, from an average BI of 3.2-3.7 at the commencement of MDT [20].

Although the $\mathrm{BI}$ indicates the presence of $M$. leprae and its DNA fragments in the lesions, some PCR methods could not identify $M$. leprae in the biopsies. This could limit the use of PCR for assessment of MDT. However, the PCR methods used may not reflect the state of the DNA of M. leprae during the MDT. It is possible that certain DNA of $M$. leprae is more vulnerable to the drugs that were used in MDT. Application of RT-PCR promises to be a more useful tool in assessing the efficacy of MDT. Comparison of PCR results among longitudinal biopsies could show more dynamic changes in the numbers of $M$. leprae in the lesions.

It is well known that the removal of $M$. leprae and its DNA depends on macrophages in the leprosy granuloma. It usually takes 5-6 years to abolish all traces of M. leprae in MB cases. This conclusion is supported by the fact that the IgM antibody for PGL-1 persisted for several years after the cessation of MDT. We could not find any report about changes in the RNA of $M$. leprae after MDT, but it is plausible that some of the RNA can last for $>1$ year. This proposition is supported by the results of the present study, which showed a clear band of RT-PCR after MDT, and by the observations of Jamil et al., who noted that the MI of patients was $1-3 \%$ at 12 and 24 months after MDT was started [14]. Thus, the results of the present study showed that $18-\mathrm{kDa}$ PCR and RT-PCR for mRNA of the $18-\mathrm{kDa}$ gene are more effective tools for following the efficacy of MDT 


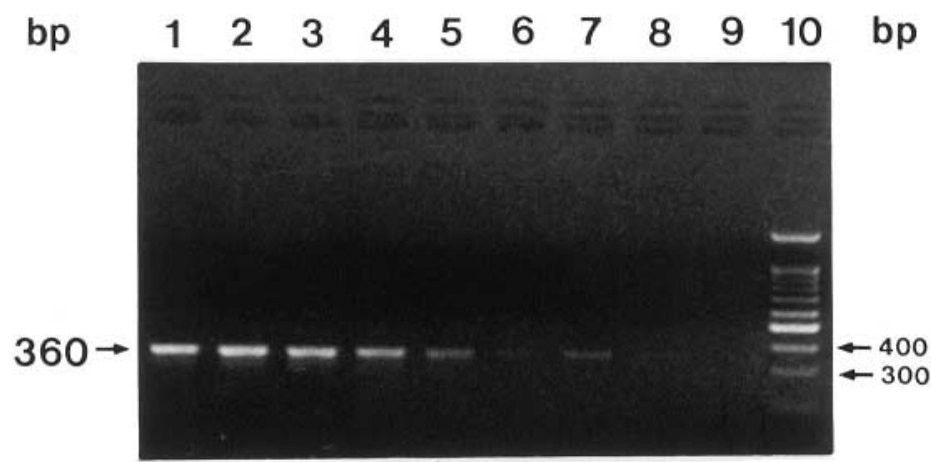

Fig. 2. Gradual decrease in the intensity of the 360-bp band in agarose gel electrophoresis from RT-PCR for 18-kDa mRNA. Lane 1, 0 month; 2, 3 months; 3, 12 months after MDT from patient no. 31 (no change in band thickness, this proved to be a mutation in gyrA of the M. leprae in SSCP). Lane 4, 0 month; 5, 3 months; 6, 12 months after MDT from patient no. 16. Lane 7, 0 month; 8, 6 months; 9, 12 months after MDT from patient no. 18. Lane 10, 100-bp ladder.

than the $\mathrm{BI}$ or $\operatorname{IgM}$ antibody titre for PGL-1 in $\mathrm{MB}$ cases.

This work was supported by a grant (\#HMP-96-M-2-0025) from the Good Health R Project, Ministry of Health and Welfare, ROK and the Catholic Medical Center Research Foundation in the programme year of 1999. We thank Mr Se-Kon Kim, Mr Pil-Soo Kang and Ms HeeSuk Lee for their technical support.

\section{References}

1. Waters MF, Rees RJ. Changes in the morphology of Mycobacterium leprae in patients under treatment. Int J Lepr 1962; 30: 266-277.

2. Shepard CC. The experimental disease that follows the injection of human leprosy bacilli into foot-pads of mice. $J$ Exp Med 1960; 112: 445-454.

3. Fine PEM, Pounighaus JM, Burgess P, Clarkson JA, Draper CC. Seroepidemiological studies of leprosy in northern Malawi based on an enzyme-linked immunosorbent assay using synthetic glycoconjugate antigen. Int J Lepr Other Mycobact Dis 1998; 66: 243-254.

4. Cho S-N, Cellona RV, Fajardo TT et al. Detection of phenolic glycolipid-1 antigen and antibody in sera from new and relapsed lepromatous patients treated with various drug regimens. Int J Lepr Other Mycobact Dis 1991; 59: 25-31.

5. Young DB, Harnisch JP, Knight J, Buchanan TM. Detection of phenolic glycolipid I in sera from patients with lepromatous leprosy. J Infect Dis 1985; 152: 1078-1081.

6. Plikaytis BB, Gelber RH, Shinnick TM. Rapid and sensitive detection of Mycobacterium leprae using a nested-primer gene amplification assay. J Clin Microbiol 1990; 28: 1913-1917.

7. de Wit MY, Faber WR, Krieg SR et al. Application of a polymerase chain reaction for the detection of Mycobacterium leprae in skin tissues. J Clin Microbiol 1991; 29: 906-910.

8. Williams DL, Gillis TP, Fiallo $\mathrm{P}$ et al. Detection of Mycobacterium leprae and the potential for monitoring antileprosy drug therapy directly from skin biopsies by PCR Mol Cell Probes 1992; 6: 401-410.

9. Yoon K-H, Cho S-N, Lee M-K et al. Evaluation of polymerase chain reaction amplification of Mycobacterium leprae-specific repetitive sequence in biopsy specimens from leprosy patients. J Clin Microbiol 1993; 31: 895-899.

10. Shepard CC, McRae DH. A method for counting acid-fast bacteria. Int J Lepr Other Mycobact Dis 1968; 36: 78-82.

11. Williams DL, Gillis TP, Booth RJ, Looker D, Watson JD. The use of a specific DNA probe and polymerase chain reaction for the detection of Mycobacterium leprae. J Infect Dis 1990; 162: 193-200.

12. Cox RA, Kempsell K, Fairclough L, Colston MJ. The $16 \mathrm{~S}$ ribosomal RNA of Mycobacterium leprae contains a unique sequence which can be used for identification by the polymerase chain reaction. $J$ Med Microbiol 1991; 35: $284-290$

13. Jamil S, Wilson SM, Hacket M, Hussain R, Stoker NG. A colorimetric PCR method for the detection of $M$. leprae in skin biopsies from leprosy patients. Int J Lepr Other Mycobact Dis 1994; 62: 512-520.

14. Jamil S, Keer JT, Lucas SB et al. Use of polymerase chain reaction to assess efficacy of leprosy chemotherapy. Lancet 1993; 342: 264-268.

15. Wichitwechkarn J, Karnjan S, Shuntawuttisettee S, Sornprasit C, Kampirapap K, Peerapakom S. Detection of Mycobacterium leprae infection by PCR. J Clin Microbiol 1995; 33: 45-49.

16. Kampirapap K, Singtham N, Klatser PR, Wiriyawipart S. DNA amplification for detection of leprosy and assessment of efficacy of leprosy chemotherapy. Int J Lepr Other Mycobact Dis 1998; 66: 16-21.

17. Donoghue HD, Holton J, Spigelman M. PCR primers that can detect low levels of Mycobacterium leprae DNA. J Med Microbiol 2001; 50: 177-182.

18. Kurabachew M, Wondimu A, Ryon JJ. Reverse transcriptionPCR detection of Mycobacterium leprae in clinical specimens. $J$ Clin Microbiol 1998; 36: 1352-1356.

19. van der Vliet GM, Cho SN, Kampirapap $\mathrm{K}$ et al. Use of NASBA RNA amplification for detection of Mycobacterium leprae in skin biopsies from untreated and treated leprosy patients. Int J Lepr Other Mycobact Dis 1996; 64: 396-403.

20. Ganapati R, Pai VV, Shroff HJ, Gandewar K. Rate of decline in bacterial index in leprosy; observations after three different chemotherapeutic interventions. Int J Lepr Other Mycobact Dis 1997; 65: 264-266. 